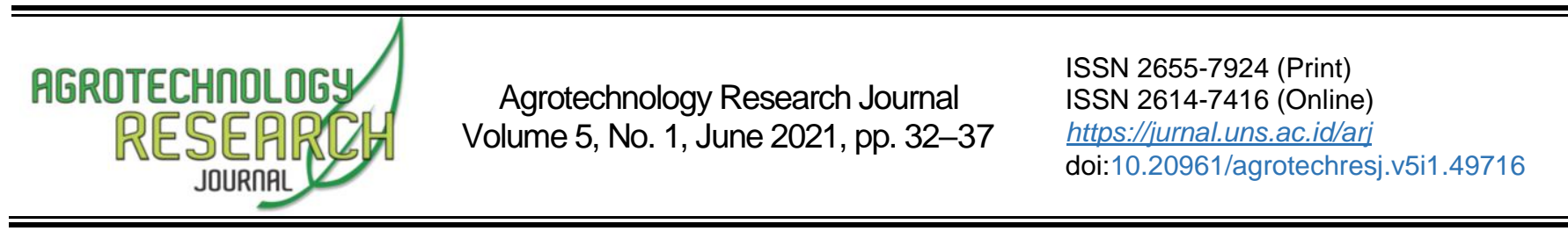

\title{
Identification and Characterization of Antagonistic Bacteria from Coffee Plant Litter
}

\author{
Gallyndra Fatkhu Dinata ${ }^{1}$, Luqman Qurata Aini2 ${ }^{*}$, Restu Rizkyta Kusuma ${ }^{3}$ \\ ${ }^{1-3}$ Department of Plant Pest and Disease, Faculty of Agriculture, Universitas Brawijaya, Malang, Jawa Timur, 65145 Indonesia
}

Received 20 March 2021; Accepted 06 May 2021; Published 30 June 2021

\begin{abstract}
Nowadays, the use of antagonistic bacteria is widely applied in agriculture and used as biological control. A previous study which is yet to be identified based on physiological and biochemical characterizations discovered these organisms present in coffee plant litter could control fusarium wilt disease. Therefore, this study is a follow-up analysis that aims to identify coffee litter antagonistic bacteria with the ability to control fusarium wilt disease. The investigation techniques used were biochemical tests comprising of endospore staining, yellow colony growth test on media, bacterial purification and screening, macroscopic and microscopic characterization, Gram, the solubility of $3 \% \mathrm{KOH}$, fermentative oxidative, fluorescent pigment production, catalase, hypersensitivity, nitrogen-fixing, and phosphate solvent test. The results showed that antagonistic bacteria, including Bacillus mycoides, Clostridium, Pseudomonas, Erwinia, and Alcaligenes sp. were identified based on their character traits. This study represents new information on the bacteria types from coffee litter to control pathogenic fungi as an environmentally friendly biological control agent.
\end{abstract}

Keywords: Beneficial bacteria; Biological control; Fusarium oxysporum

Cite this as (CSE Style): Dinata GF, Aini LQ, Kusuma RR. 2021. Identification and characterization of antagonistic bacteria from coffee plant litter. Agrotechnology Res J. 5(1): 32-37. https://dx.doi.org/10.20961/agrotechresj.v5i1.49716.

\section{INTRODUCTION}

The adoption of plant growth-promoting bacteria (PGPB) as biofertilizers in agriculture has shown great promise in providing an effective and eco-friendly approach in ensuring food security (Glick 2014). Antagonistic bacteria are examples of microorganism with these prospects, where its applications in the prevention of plant diseases and growth are now widely applied in agriculture. Currently, several antagonistic bacteria are used as biological control, which also reduces the negative impact of using fungicides. Furthermore, some of the antagonistic microbes from fungi, including Gliocladium sp. and Trichoderma sp. (Agrios 2005), and bacteria, including Pseudomonas fluorescens and Bacillus sp., have been reported as a biological control for fusarium wilt (Saputra et al. 2015).

Nutrient cycle is an important process where the dead and fallen plant part, known as litter balances nutrients for each component in an ecosystem (Fadiji and Babalola 2020). Furthermore, litter biodegradation is a method of returning waste minerals into the ecosystem to a level where these substances can be used by organisms and turned into a sustainable chain process. The role of bacteria isolated from litter has been previously shown in several studies, where endophytic

\section{${ }^{*}$ Corresponding Author:}

E-Mail: luqman.fp@ub.ac.id microbes provide an important function in the biodegradation of host plant litter (Promputtha et al. 2010). In this process, endophytic microbes colonize plants and trigger saprophytic organisms to act through antagonistic reactions (Nair and Padmavathy 2014). Also, some of the isolated bacteria from litter include Bacillus, Clostridium, Enterobacteria, Bacteroides, Plesiomonas, Bordetella, Streptococcus, and Neisseria sp. (Yulma et al. 2017). Also, bacteria isolated from South Andaman mangrove litter was revealed to contain 38 bacteria with the dominant one being Bacillus spp. (Yahya et al. 2014).

The potential of antagonistic bacteria from coffee plant litter in UB Forest in the control of various plant diseases was previously discovered. Also, a new ability for bacteria in the control of fusarium wilt disease in shallots has been discovered but is yet to be identified and no further characteristics have been conducted in previous studies. Fusarium wilt is the main problem in shallot farming in Indonesia, where this disease is caused by Fusarium oxysporum f. sp. cepae (Hanz) Snyd. \& Hans (Hadiwiyono et al. 2009). The disease is important because it attacks the soil and also infects plants in the storage process (Widodo et al. 2008).

Based on the description above, this study aims to identify the antagonistic bacteria from coffee plant litter. This is expected to resolve the stages of the various antagonistic bacteria identification processes for researchers or academics. 


\section{MATERIALS AND METHODS}

\section{Purification of antagonistic bacteria}

The antagonistic bacteria isolate collection HPT UB by Dinata (2018) from the stock was grown for the first time on Nutrient Agar (NA) medium to ensure its purity.

\section{Bacterial screening}

In screening for antagonists and bacteria, the dual culture with modified filter paper by Djatnika (2012) and PDA media by the existing colonies of $F$. oxysporum were used. The PDA media was made in circles using a cork borer of $5 \mathrm{~mm}$ in diameter and then placed on the PDA media in a Petri dish of diameter $9 \mathrm{~cm}, 3 \mathrm{~cm}$ from the edge. Furthermore, round cuts were simultaneously prepared with a sterile filter paper of diameter $9 \mathrm{~mm}$ and dipped in the antagonistic bacterial candidate suspension for 1 minute. Subsequently, these cuts drained in a sterile petri dish until excess water removed and pieces of filter paper with bacteria on media inoculated against $F$. oxysporum with a distance of $3 \mathrm{~cm}$ was incubated in the Petri dishes at room temperature. Observations on the seventh day included the radius of the organism's colony facing the bacterial variant $(r 1)$ and the edge of the petri dish ( $r 2)$. The percentage of resistance was calculated using the following formula:

$P($ percentage of resistance $)(\%)=\{(r 2-r 1) / r 2\} \times 100 \%$

\section{Macroscopic observation}

Macroscopic observations, including shape, elevation, edges, and colony color produced on NA media were observed through a magnifying glass or light microscope.

\section{Hypersensitivity test}

This test aims to determine the pathogenicity of bacterial isolates. The bacterial suspension is infiltrated on the tobacco leaf through its bone, where hypersensitivity symptoms occur when the part infiltrated with bacterial supposition undergoes necrosis within 1-4 days (Klement 1990 in Fanani et al. 2015).

\section{Characterization of bacteria}

Characterization was conducted by comparing bacterial properties based on identification keys from Bergey's Manual of Determinative Bacteriology Volume 1 (Bergey et al. 1984; Schaad et al. 2001). Some of the methods used include:

\section{Gram test}

Pure bacteria cultured for 24 hours are formulated into a suspension with sterile distilled water. Furthermore, one loop of the bacteria is placed on a sterilized object-glass over a Bunsen fire until dry, then 1 drop of crystal violet is painted and left for 1 minute, washed with running water, and let dry over the Bunsen fire. The next step is to drop the object-glass with iodine solution and let it sit for 1 minute, then wash with running water and air dry. Subsequently, drip the object-glass with $70 \%$ alcohol for 1 minute, wash with running water, air dry, paint using safranin for 1 minute, and then wash with running water and dry. The observations were conducted under a microscope with 1000x magnification and dropped in oil immersion. Furthermore, Grampositive and Gram-negative bacteria showed a purple and red color, respectively (Schaad et al. 2001).

\section{Solubility test of $3 \% \mathrm{KOH}$}

Bacteria cultured for 24 hours were suspended on a glass slide previously dripped with $3 \% \mathrm{KOH}$. The suspension was pulled upward or lifted using a loop needle, where a positive and negative reaction occurred when the bacteria did not form mucus strings and when the suspension formed threads or mucus, respectively (Schaad et al. 2001).

\section{Endospores staining}

Endospore staining aims to determine the spore formation of bacteria. The Bartholomew-Mittwer method was used to conduct this test, where a 24-hour old culture was suspended in a glass slide carried over a Bunsen. Subsequently, 2 drops of malachite green were added for 10 minutes, washed with running water, and air-dried. In addition, the culture was dripped with safranin for 1 minute, washed with running water, and then dried. The preparation was observed under a microscope, where bacteria formed greenish spores and its cells red (Schaad et al. 2001).

\section{Fermentative oxidative test}

This test was conducted by growing the bacteria on glucose fermentation media with a pH of 7 in a test tube. The media consisted of 2, 5, 0.3, and $3 \mathrm{~g}$ of peptone, $\mathrm{NaCl}, \mathrm{KH}_{2} \mathrm{PO}_{4}$, and agar, respectively as well as $3 \mathrm{ml}$ of Bromothymol blue (1\%). Furthermore, the material was mixed and dissolved in 1 liter of distilled water and then sterilized. Each tube was added aseptically with $0.5 \mathrm{ml}$ of $10 \%$ glucose solution and the 24 -hour-old pure culture of bacteria inserted into 2 test tubes that already contained fermentative oxidative solid media. Also, one of the tubes was covered with agar water and incubated for 7-14 days, where no color change indicated an oxidative reaction while a change in both tubes show a fermentative reaction (Schaad et al. 2001).

\section{Fluorescent pigment production test}

Fluorescent pigment testing aims to determine the ability of bacteria to produce fluorescent pigments. These organisms were grown on King's B selective media by streak plate method and incubated for $24-48$ hours, and then observed in ultraviolet (UV) light. The reaction is positive if the bacteria produce a fluorescent green pigment (Schaad et al. 2001).

\section{Yellow colony growth on YDC media}

The yellow colony growth test on YDC media aims to view the growth of bacterial colonies which can be differentiated into the genus Pantoea or Erwinia. YDC media consisted of $10,20,20$, and $15 \mathrm{~g}$ of yeast extract, glucose, $\mathrm{CaCO}_{3}$, and agar, respectively dissolved in 1 liter of distilled water. The media was sterilized by autoclave at $121^{\circ} \mathrm{C}$ and the bacteria scratched on the medium and incubated at $30^{\circ} \mathrm{C}$. Furthermore, a positive reaction occurs when a yellow colony known as a bacterium from the genus Pantoea and a white colony from the genus Erwinia is formed (Schaad et al. 2001).

\section{Nitrogen fixing test}

The nitrogen fixation test was conducted qualitatively by growing bacterial colonies on Burk media which is selective for nitrogen-fixing bacteria. This media composition consists of glucose $(10 \mathrm{~g})$, agar $(1.8 \mathrm{~g})$, $\mathrm{KH}_{2} \mathrm{PO}_{4}(0.41 \mathrm{~g}), \mathrm{UB}_{2} \mathrm{HPO}_{4}(0.52 \mathrm{~g}), \mathrm{Na}_{2} \mathrm{SO}_{4}(0.05 \mathrm{~g})$, 
$\mathrm{CaCl}_{2}(0.2 \mathrm{~g}), \mathrm{MgSO}_{4} .7 \mathrm{H}_{2} \mathrm{O}(0.1 \mathrm{~g}), \mathrm{FeSO}_{4} .7 \mathrm{H}_{2} \mathrm{O}(0.005$ $\mathrm{g})$, and $\mathrm{Na}_{2} \mathrm{MoO}_{4} .2 \mathrm{H}_{2} \mathrm{O}(0.0025 \mathrm{~g})$ dissolved in $1000 \mathrm{~mL}$ of distilled water. Observations on the growth of bacterial colonies were conducted 24 hours after incubation. Also, Burk media is a medium containing inorganic salts with a source of carbohydrates and without the inclusion of nitrogen. The bacterial isolates that were able to grow on the media showed the tested bacterial isolates were able to fix nitrogen (Deshwal and Kumar 2013).

\section{Phosphate solvent test}

Phosphate solvent testing was conducted by growing all bacterial colonies on Pikovskaya's medium which is selective for phosphate solubilizing bacteria. The composition of the media consists of yeast extract $(0.25$ g), agar $(10 \mathrm{~g})$, dextrose $(5 \mathrm{~g}), \mathrm{Ca}_{3}\left(\mathrm{PO}_{4}\right)^{2}(2.5 \mathrm{~g})$, $\left(\mathrm{NH}_{4}\right)^{2} . \mathrm{SO}_{4}(0.25 \mathrm{~g}), \mathrm{KCL}(0.1 \mathrm{~g}), \mathrm{MgSO}_{4} .7 \mathrm{H}_{2} \mathrm{O}(0.05 \mathrm{~g})$, $\mathrm{MnSO}_{4} .2 \mathrm{H}_{2} \mathrm{O}(0.005 \mathrm{~g})$, and $\mathrm{FeSO}_{4} .7 \mathrm{H}_{2} \mathrm{O}(0.005 \mathrm{~g})$, dissolved in $1000 \mathrm{~mL}$ of distilled water. Furthermore, 1 loop of the bacterial isolates was inoculated on Pikovskaya's media, incubated at $\pm 28^{\circ} \mathrm{C}$ for 3 days, and then a clear zone was observed. Isolates with the ability to dissolve phosphate are characterized by the formation of a clear zone due to colony growth (Himedia 2015).

\section{Analysis and presentation}

The data obtained were analyzed descriptively based on the morphological characters of the colony and bacterial cells. Furthermore, the physiological and biochemical test results, as well as the identification results, were displayed in Tables and Figures (Photos).

\section{RESULTS AND DISCUSSION}

The screening results showed there were 21 bacterial isolates with antagonistic properties (Table 1). Furthermore, five bacteria, including UB1, UB2, UB11, UB13, and UB29 with the largest inhibition percentage of $60-66 \%$ were identified.

\section{Colony morphology and bacterial cells}

The results of the antagonistic bacteria isolation from coffee litter were discovered in five isolates which resulted in different colony morphology and bacterial cells. In the form of bacterial colonies, coffee litter antagonists are generally circular, white, and yellow with a convex elevation and flat as well as uneven edges.

Table 2 and Figure 1 showed the microscopic observations of cells, where all antagonistic bacteria have a rod cell shape with forms known as monobacil and streptobacil. The monobacil form is a bacterial cell with a rod shape that does not form a chain while the streptobacil develops an elongated chain of rods.

\section{Biochemical characterization of bacteria}

There are three Gram-negative and two Grampositive bacteria based on the Gram's staining test and the solubility test of $3 \% \mathrm{KOH}$ where UB1 and UB2 were positive. This can be seen on the Gram-stain where the bacterial cells are violet and on the results of the solubility test $3 \% \mathrm{KOH}$ which did not produce a thick suspension. The Gram-positive bacteria retain the crystal violet stain and appear purple when observed under a microscope. Meanwhile, the Gram-positive cell wall appears as a broad, $20-80 \mathrm{~nm}$ thick dense wall consisting of multiple interconnected layers of 60 to $90 \%$ peptidoglycan (Kaiser 2021).

On the contrary, there are three Gram-negative bacteria, including UB3, UB4, and UB5. The results showed red cells and thick suspension for the Gram's staining and the solubility test of $3 \% \mathrm{KOH}$, respectively. In Gram-negative bacteria, the cell wall consists of 1-3 layers which are easily disturbed releasing thick chromosomal material causing the bacterial suspension to become thick and stringy If given $3 \% \mathrm{KOH}$ (Madigan et al. 2012). Figure 2 shows UB1 and UB2 are Grampositive producing endospores which are defense tools used by bacteria to survive in non-determining conditions with an oval shape similar to an egg. These isolates' bacteria appear green and are located separately from the red cells. Based on observations of colony morphological characters, cell morphology, and biochemical tests, five genera of antagonistic bacteria, including Bacillus mycoides, Clostridium, Pseudomonas, Erwinia, and Alcaligenes sp. were isolated from coffee litter.

Table 1. Percentage inhibition of bacterial screening

\begin{tabular}{ll|ll|ll}
\hline Isolate & Inhibitory (\%) & Isolate & Inhibitory (\%) & Isolate & Inhibitory (\%) \\
\hline UB1 & $\mathbf{6 6 . 0 0}$ & UB11 & $\mathbf{6 0 . 0 0}$ & UB21 & - \\
UB2 & $\mathbf{6 0 . 0 0}$ & UB12 & - & UB22 & - \\
UB3 & 33.33 & UB13 & $\mathbf{6 2 . 2 2}$ & UB23 & - \\
UB4 & 33.33 & UB14 & 55.55 & UB24 & - \\
UB5 & - & UB15 & 33.33 & UB25 & 46.66 \\
UB6 & - & UB16 & 46.67 & UB26 & 51.11 \\
UB7 & - & UB17 & 48.88 & UB27 & 31.11 \\
UB8 & 48.88 & UB18 & 55.55 & UB28 & 44.44 \\
UB9 & 48.88 & UB19 & 51.11 & UB29 & $\mathbf{6 0 . 0 0}$ \\
UB10 & - & UB20 & 55.55 & UB30 & 46.88 \\
\hline
\end{tabular}


Table 2. Cell morphology of antagonistic bacterial isolates

\begin{tabular}{lllllc}
\hline \multirow{2}{*}{ Cell morphology } & \multicolumn{5}{c}{ Isolates } \\
\cline { 2 - 6 } & UB1 & UB2 & UB11 & UB13 & UB29 \\
\hline Form & Rod & Rod & Rod & Rod & Rod \\
Color & Purple & Purple & Red & Red & Red \\
Size of cell $(\mu \mathrm{m})$ & $3.14-4.15$ & $3.27-5.50$ & 3.27 & $3.34-4.12$ & 2.54 \\
Endospore & Positive & Positive & - & - & - \\
Size of endospore $(\mu \mathrm{m})$ & $2.78-2.83$ & 2.63 & - & - & - \\
\hline
\end{tabular}
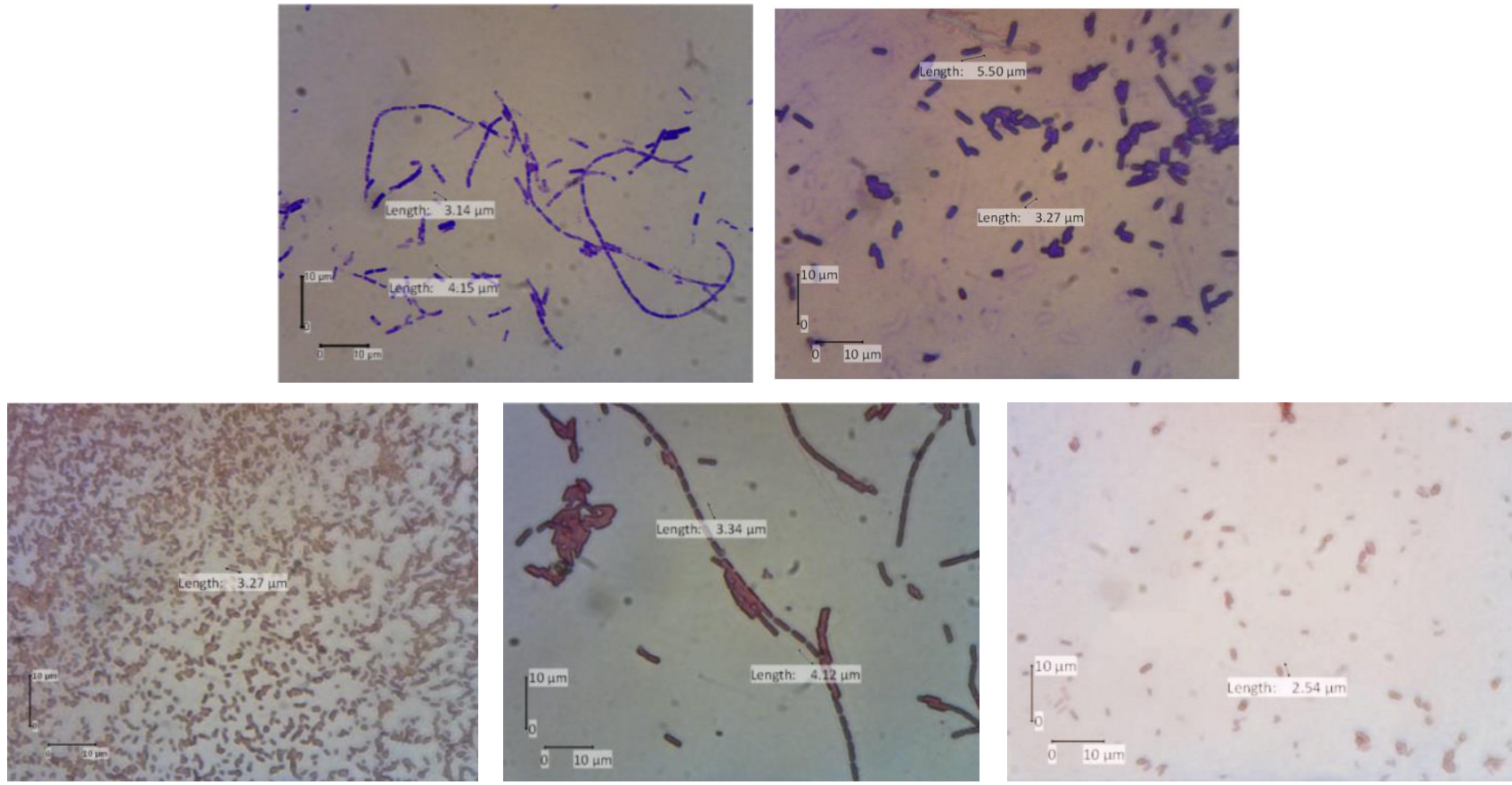

Figure 1. Gram-positive bacteria with violet cells; B. mycoides, and Clostridium sp., (top), Gram-negative bacteria with red cells; Pseudomonas, Erwinia, and Alcaligenes sp. (bottom)
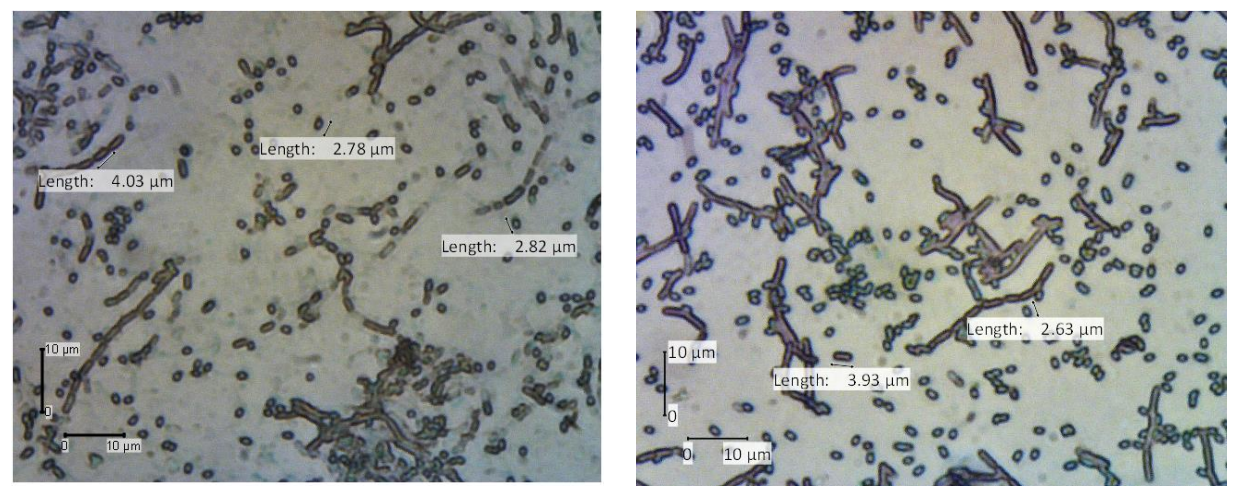

Figure 2. Endospore morphology of Gram-positive bacteria, where green colours are endospore and red are cells. B. mycoides (left) and Clostridium sp. (right)

UB1 has a colony morphology in the form of fibers (filamentous) curved clockwise, with cream color, uneven edges, and flat elevation. The cell morphology shows these bacteria are Gram-positive with rodshaped, purple, paired cells forming long chains with a size of $3.14-4.15 \mu \mathrm{m}$. Figure 2 the bacteria produce green oval endospores with a size of $2.78-2.82 \mu \mathrm{m}$. In the biochemical test, this isolate was fermentative, producing a positive reaction in the catalase test, and was unable to generate fluorescent pigments while in the hypersensitivity test, negative UB1 isolate caused necrosis in tobacco leaves. According to Bergey's Manual of Systematic Bacteriology and Schaad et al. (2001), bacteria with these characteristics belong to the genus Bacillus. The characteristic features of UB1 isolate include a fibrous colony shape resembling Bacillus mycoides with coarser fine threads around the colony, and a milk-white color (Andriani et al. 2017). 
This isolate has cells that tend to form long chains connected by uncleaved septa wall material (Errington and van der Aa 2020). Bacillus mycoides are Grampositive, rod-shaped, spore-producing bacteria where its growth forms specific rhizoids, producing cells that extend end to end, and are grouped in filamentous bundles (Yi 2018). Bacillus species are Gram-positive rods that are often paired or chain cells with round or square ends usually having a single endospore which are generally oval or sometimes round and are very resistant to adverse conditions (Public Health England 2018).

UB2 has a circular colony, cloudy white color, and flat edges with a convex elevation. The cell morphology shows Gram-positive bacteria with purple, rod-shaped cells, often paired and forming long chains with a size of $3.27-5.50 \mu \mathrm{m}$. Furthermore, the bacteria produced an oval-shaped endospore which is swollen and located separately from the bacterial cell. Figure 2 shows endospores are green with a size of $2.63 \mu \mathrm{m}$. In the biochemical test, this isolate was fermentative, producing a negative reaction in the catalase test, and was unable to produce fluorescent pigments while in the hypersensitivity test, negative UB2 isolates caused necrosis in tobacco leaves. According to Bergey's Manual of Systematic Bacteriology and Schaad et al. (2001), bacteria with these characteristics belong to the genus Clostridium.

UB11 has a circular colony, yellowish-white color, with flat edges and convex elevations. The bacterial cell morphology shows Gram-negative organisms with rodshaped, red cells, not forming chains + (monobacilli) with a size of $3.27 \mu \mathrm{m}$. In the biochemical test, this isolate was oxidative, producing a positive reaction in the catalase test, clear fluorescent pigments, and on YDC media formed yellow colonies while in the hypersensitivity test, negative UB11 isolate caused necrosis in tobacco leaves. According to Bergey's Manual of Systematic Bacteriology and Schaad et al. (2001), bacteria with these characteristics belong to the genus Pseudomonas.

UB13 has a circular colony, cloudy white color, with a wavy edge and a convex elevation. The bacterial cell morphology shows Gram-negative bacteria with rodshaped, red cells forming long chains (streptobacil) with a size of $3.34-4.12 \mu \mathrm{m}$. In the biochemical test, this isolate was fermentative, producing a positive reaction in the catalase test, unable to produce fluorescent pigments, and formed white colonies on YDC media while in the hypersensitivity test, negative UB13 isolate caused necrosis in tobacco leaves. According to Bergey's Manual of Systematic Bacteriology and Schaad et al. (2001), bacteria with these characteristics belong to the genus Erwinia.

UB29 has a circular colony, clear yellow color, with flat edges and convex elevations. The bacterial cell morphology shows Gram-negative bacteria with rodshaped, red cells that do not form chains (monobacilli) with a size of $2.54 \mu \mathrm{m}$. In the biochemical test, this isolate was oxidative, producing a positive reaction in the catalase test, fluorescent pigments, and yellow colonies on the YDC media while in the hypersensitivity test, isolate UB29 was negative causing necrosis in tobacco leaves. According to Bergey's Manual of Systematic Bacteriology and Schaad et al. (2001), bacteria with these characteristics belong to the genus Alcaligenes. These five bacteria consist of different genera and based on the results of the nitrogen-fixing test, all were able to grow on Burk media, hence, fixing nitrogen properly. However, only two isolates known as Bacillus mycoides and Pseudomonas sp. were able to grow on the Pikovskaya's media and act as good phosphate solvent candidates. These results are in line with several studies. According to several beneficial bacteria able to fix nitrogen were discovered, including Alcaligenes, Bacillus, Clostridium, Enterobacter, and Pseudomonas sp. Also, a study by Wijiyono (2009), states there are several phosphate solubilizing bacteria from mangrove soils in the Tapian Nauli Tapanuli bay area, and among the bacteria seen were $B$. mycoides and $P$. aeruginosa.

\section{CONCLUSIONS AND SUGGESTIONS}

Antagonistic bacteria isolated from coffee plant litter were identified as Bacillus mycoides, Clostridium, Pseudomonas, Erwinia, and Alcaligenes sp. This study suggests the necessity for molecular identification to discover more about these bacterial species.

\section{ACKNOWLEDGMENTS}

The authors are grateful to the Indonesian Ministry of Research, Technology, and Higher Education (Ristekdikti) in the Student Creativity Program (PKM) for funding this study.

\section{REFERENCES}

Agrios GN. 2005. Plant pathology. 5th ed. San Diego (CA): Elsevier Academic Press. 952 p.

Andriani Y, Rochima E, Safitri R, Rahayuningsih SR. 2017. Characterization of Bacillus megaterium and Bacillus mycoides bacteria as probiotic bacteria in fish and shrimp feed. KnE Life Sci. 2(6):127. https://dx.doi.org/10.18502/kls.v2i6.1029.

Benedetto NAD, Corbo MR, Campaniello D, Pia Cataldi MP, Bevilacqua A, Sinigaglia M, Flagella Z. 2017. The role of plant growth promoting bacteria in improving nitrogen use efficiency for sustainable crop production: a focus on wheat. AIMS Microbiolgy. 3(3):413-434. https://dx.doi.org/10.3934/microbiol.2017.3.413.

Bergey D, Krieg NR, Holt JG. 1984. Bergey's manual of systematic bacteriology. In: Krieg NR, Holt JG, editors. Bergey's Manual of Systematic Bacteriology . Vol. 1. Baltimore, MD : Williams \& Wilkins,. p. 516517.

Deshwal VK, Kumar P. 2013. Production of plant growth promoting substance by pseudomonads. J Acad Ind Res. 2(4):221-225.

Dinata GF. 2018. Potensi bakteri dari serasah tanaman kopi di ub forest untuk mengendalikan penyakit busuk pangkal batang (Fusarium oxysporum f.sp. cepae) pada tanaman bawang merah [Undergraduate Thesis]. Malang (ID): Brawijaya University. http://repository.ub.ac.id/id/eprint/161638.

Djatnika I. 2012. Seleksi akteri antagonis untuk mengendalikban layu Fusarium pada tanaman Phalaenopsis. J Hortik. 22(3):276-284. https://dx.doi.org/10.21082/jhort.v22n3.2012.p276-284. 
Errington J, van der Aart LT. 2020. Microbe profile: Bacillus subtilis: model organism for cellular development, and industrial workhorse. Microbiology . 166(5):425-427. https://dx.doi.org/10.1099/mic.0.000922.

Fadiji AE, Babalola OO. 2020. Exploring the potentialities of beneficial endophytes for improved plant growth. Saudi J Biol Sci. 27(12):3622-3633. https://dx.doi.org/10.1016/j.sjbs.2020.08.002.

Fanani AK, Abadi AL, Aini LQ. 2015. Eksplorasi bakteri patogen pada beberapa spesies tanaman kantong semar (Nepenthes sp.). J. HPT. 3(3):104-110.

Glick BR. 2014. Bacteria with ACC deaminase can promote plant growth and help to feed the world. Microbiol Res. 169(1):30-39. http://dx.doi.org/10.1016/j.micres.2013.09.009.

Hadiwiyono, Wuspada RD, Widono S, Poromarto SH, Fatawi ZD. 2009. Kesupresifan tanah terhadap busuk pangkal (Fusarium oxysporum f. sp. cepae) bawang putih di Tawangmangu Karanganyar. Sains Tanah: J IImu Tanah Agroklimatologi. 6(1):1-6.

Himedia. 2015. Pikovskaya's broth (medium). M1719, HiMedia Laboratories Pvt Ltd.

Kaiser G. 2021. The Gram-Positive Cell Wall. Catonsville (MD): The LibreTexts libraries; [updated 2021 Jan 4; accessed $2021 \quad$ Feb 21$]$. https://bio.libretexts.org/@go/page/3111.

Madigan MT, Martinko JM, Stahl DA, Clark DP. 2012. Brock biology of microorganisms. 13th ed. San Fansisco (CA): Pearson Education Benjamin Cummings.

Nair DN, Padmavathy S. 2014. Impact of endophytic microorganisms on plants, environment and humans. Sci World J. 2014:1-11. https://dx.doi.org/10.1155/2014/250693.

Promputtha I, Hyde KD, McKenzie EHC, Peberdy JF, Lumyong S. 2010. Can leaf degrading enzymes provide evidence that endophytic fungi becoming saprobes? Fungal Divers. 41:89-99. https://dx.doi.org/10.1007/s13225-010-0024-6.
Public Health England. 2018. Identification of Bacillus species. UK Standards for Microbiology Investigations. London (UK): Standards Unit, Microbiology Services, PHE. 9(3.1):p. 9.

Saputra R, Ariwiyanto T, Wibowo A. 2015. Uji aktivitas antagonistik beberapa isolat bacillus spp. terhadap penyakit layu bakteri (Ralstonia solanacearum) pada beberapa varietas tomat dan identifikasinya. Pros Semin Nas Masy. Biodiversitas Indones. 1(5):11161122.

Schaad N, Jones JB, Chun W. 2001. Laboratory guide for identification of plant pathogenic bacteria. 3rd Ed. St. Paul (USA): American Phytopathological Society Press. 373 p. https://dx.doi.org/10.1046/j.1365-3059.2001.00635.x.

Widodo, Kondo N, Kobayashi K, Ogoshi A. 2008. Vegetative compatibility groups within Fusarium oxysporum f. sp. cepae in Hokkaido-Japan. Microbiol Indones. 2(1):39-43. https://dx.doi.org/10.5454/mi.2.1.8.

Wijiyono. 2009. Keanekaragaman bakteri serasah daun Avicennia marina yang mengalami dekomposisi pada berbagai tingkat salinitas di teluk Tapian Nauli [master's thesis]. Medan (ID): Universitas Sumatera Utara.

Yahya Y, Nursyam H, Yenny R, Soemarno S. 2014. Karakteristik bakteri di perairan Mangrove pesisir Kraton Pasuruan. Ilmu kelautan: Indones J Mar Sci. 19(1):3542. https://dx.doi.org/10.14710/ik.ijms.19.1.35-42.

Yi Y. 2018. Bacillus mycoides: novel tools for studying the mechanisms of its interaction with plants.

Yulma Y, Ihsan B, Sunarti S, Malasari E, Wahyuni N, Mursyban M. 2017. Identifikasi bakteri pada serasah daun Mangrove yang terdekomposisi di kawasan Konservasi Mangrove dan Bekantan (KKMB) Kota Tarakan. J Trop Biodivers Biotechnol. 2(1):28. https://dx.doi.org/10.22146/jtbb.27173. 